\title{
Studi kritis model perjanjian muḍārabah pada perbankan syariah di Indonesia
}

\author{
Muhammad Sjaiful \\ Fakultas Hukum Universitas Halu Oleo \\ E-mail: saifulhamad@gmail.com
}

The presence of Islamic Banking in Indonesia on the one hand it should be welcomed because it is a proof of the excitement of the majority of Muslims in the country to attempt to practice the teachings of Islam in the life of the muamalah each other. But very unfortunate if the concept of Islamic Banking is still graft the principles of usury-based conventional banks. As shown in the mudaraba agreement scheme practiced by some Islamic Bank is still causing some problems from the viewpoint of Sharia, including Islamic Banking legal standing as related parties in the mudaraba agreement itself, the dual status, on the one side and the other side as mudarib as șabib al mal. Held dual status that Islamic Banking course diametrically opposed to the principles of sharia. Another serious problem that was seized in Mudarabah current agreement scheme is a scheme which is essentially an agreement contract debts between Islamic Bank is positioning itself as a cabib al-mal with customers who position themselves as mudärib. Being stuck mud arabah made Islamic Bank debts into the scheme of course is very dangerous from the point of view of sharia because it would trap the usury-based parties in the transaction. For the reconstruction of the model that needs to be done mudaraba agreement on Islamic banking that models the agreement actually purely on the basis of pure sharia upright.

Kehadiran Perbankan Syariah di Indonesia pada satu sisi memang patut disambut gembira karena ini merupakan salah satu bukti dari kegairahan dari mayoritas umat Islam di tanah air untuk berupaya mengamalkan ajaran Islam dalam kehidupan muamalahnya satu satu sama lain. Namun yang sangat disayangkan bila konsep Bank Syariah saat ini masih mencangkokkan prinsip-prinsip bank konvensional yang berbasis ribawi. Seperti yang tampak pada skema perjanjian mudärabah yang dipraktekkan oleh beberapa Bank Syariah masih menimbulkan beberapa problem dari sudut pandang syariah, antara lain legal standing Bank Syariah sebagai pihak terkait dalam perjanjian mudärabah itu sendiri, yang berstatus ganda, disatu sisi sebagai mudärib dan disisi lain sebagai șaḥib al-māl. Status ganda yang dimiliki Bank Syariah itu tentu saja bertentangan secara diametral dengan prinsip-prinsip syariah. Problem serius lain yang tengah dihinggapi dalam skema perjanjian mudärabah saat ini adalah skema perjanjian yang pada hakikatnya merupakan akad utang piutang antara Bank Syariah yang memposisikan diri sebagai șăhibul mäl dengan nasabah yang memposisikan diri sebagai mudärib. Keterjebakan akad mudärabah yang dibuat 
ljtihad, Jurnal Wacana Hukum Islam dan Kemanusiaan, Volume 15, No. 1, Juni 2015: 119-136

Bank Syariah kedalam skema utang piutang tentu saja sangat berbahaya dari sudut pandang syariah karena bakal menjebak para pihak dalam transaksi berbasis ribawi. Untuk itulah perlu dilakukan rekonstruksi model perjanjian mudärabah pada perbankan syariah agar model perjanjian tersebut betulbetul murni tegak atas dasar murni syariah.

Keywords: Sharia banking; Mudarabab; Customer; Loan

\section{Pendahuluan}

Salah satu kebersyukuran dari umat Islam Indonesia, yakni pemegang otoritas kekuasan di Indonesia telah menggaransi kehidupan hukum bagi masyarakat Islam Indonesia melalui legalisasi beberapa nilai-nilai hukum terutama berkaitan dengan bidang-bidang hukum privat termasuk bidang hukum munakahat ke dalam produk undang-undang nasional, seperti Undang-Undang Nomor 1 Tahun 1974 tentang Perkawinan dalam Lembaran Negara RI Nomor 1 Tahun 1974, Undang-Undang Nomor 41 Tahun 2004 tentang Wakaf dalam Lembaran Negara RI Nomor 159 Tahun 2004, Undang-Undang Nomor 3 Tahun 2006 tentang Perubahan Undang-Undang Nomor 7 Tahun 1989 tentang Peradilan Agama dalam Lembaran Negara RI Nomor 22 Tahun 2006, Undang-Undang Nomor 21 Tahun 2008 tentang Perbankan Syariah dalam Lembaran Negara RI Nomor 94 Tahun 2008, Instruksi Presiden Nomor 1 Tahun 1991 tentang Kompilasi Hukum Islam yang dikeluarkan oleh Presiden RI pada tanggal 10 Juni 1991, dan Peraturan Mahkamah Agung Republik Indonesia Nomor 2 Tahun 2008 tentang Kompilasi Hukum Ekonomi Syariah yang ditetapkan oleh Ketua Mahkamah Agung tanggal 10 September 2008, serta masih banyak lagi peraturan hukum tertulis lainnya yang mengatur tentang bidang-bidang keperdataan yang tunduk berdasarkan dogma hukum Islam.

Mencermati berbagai produk hukum tertulis yang mengatur berbagai hubungan hukum privat bagi masyarakat muslim di Indonesia tersebut, semakin menunjukkan bahwa masyarakat muslim Indonesia telah mendapat legalitas untuk mengatur hubungan-hubungan hukum privat mereka dengan berbasis kepada Syariah Islam, mulai dari hukum keluarga, hukum perkawinan, hukum waris, bahkan juga untuk bidang-bidang transaksi keuangan.

Adapun untuk bidang-bidang transaksi keuangan, masyarakat muslim di Indonesia, sudah bisa menyaksikan kehadiran berbagai lembaga keuangan yang mengakomodir kepentingan mereka dengan tetap berpijak kepada sebuah hubungan transaksi yang berlandaskan hukum 
ekonomi menurut prinsip-prinsip syariah. Sebagai contoh untuk memperkuat argumentasi ini adalah dengan menyemaraknya kehadiran perbankan syariah, kemudian ada yang disebut asuransi syariah, dan terakhir yang dapat kita amati adalah kehadiran pegadaian syariah (Azis, et.al, 2010: 52).

Salah satu produk syariah yang diperkenalkan dalam perbankan syariah kontemporer di Indonesia, yaitu apa yang disebut dengan perjanjian mudărabah. Model perjanjian ini sesungguhnya berlandaskan kepada perjanjian usaha bersifat komersil untuk mendapatkan keuntungan (profit). Tentu saja model perjanjian mudărabah yang diperkenalkan perbankan syariah di Indonesia haruslah berpijak kepada spririt syariah sebagai sesuatu yang tidak boleh ditawar-tawar lagi karena sebuah produk perjanjian yang diklaim berbasis syariah maka aqidah Islam mestinya juga menjadi pijakannya.

Fakta perjanjian mudāabah yang diperkenalkan beberapa perbankan syariah di Indonesia ternyata masih mentransplantasi model perjanjian berbasis perbankan konvensional, sehingga terkesan konsep perjanjian muḍarabah yang nyaris melenceng dari prinsip-prinsip syariah. Hasil pengamatan sementara tim peneliti pada klausula perjanjian muḍarabah pada PT Bank Muamalat Cabang Kendari pada Maret 2014, ternyata terdapat beberapa klausula bermasalah yang masih memosisikan bank syariah pada posisi ganda, yaitu disatu sisi bank syariah mendudukkan dirinya sebagai pelaku usaha dan disisi lain bank syariah memposisikan diri sebagai pemilik modal. Kedudukan ganda sebagai subjek hukum perjanjian muḍarabah bagi bank syariah tentu merupakan sesuatu yang sangat krusial yang dapat menjebak para pihak dalam perjanjian mudārabah, yang justeru keluar dari spririt syariah. Padahal gagasan pendirian perbankan syariah tidak lain adalah untuk menggaransi pelaksanaan prinsip-prinsip syariah bagi masyarakat muslim Indonesia yang hendak menjamin penyempurnaan aqidahnya dibidang muamalah.

Untuk itulah, penelitian terhadap nomenklatur perjanjian mudărabah yang dipraktekkan beberapa lembaga perbankan syariah di Indonesia, sangat perlu dilakukan guna mengetahui titik kritis kalusula perjanjian yang justeru menyalahi prinsip-prinsip syariah. Agar perjanjian muḍarabah yang dipraktekkan selama ini, tidak melenceng dari prinsip-prinsip syariah yang baku.

Berdasarkan uraian latar belakang masalah, maka yang menjadi pokok-pokok rumusan masalah penelitian ini, adalah: Apakah perjanjian mudărabah yang dipraktikkan pada perbankan 
ljtihad, Jurnal Wacana Hukum Islam dan Kemanusiaan, Volume 15, No. 1, Juni 2015: 119-136

syariah di Indonesia telah memenuhi kriteria normatif menurut Syariah Islam? Berpijak kepada rumusan masalah tersebut, maka tujuan penelitian secara spesifik adalah: Untuk melakukan studi terhadap anatomi perjanjian mu

arabah yang dipraktikkan pada perbankan syariah di Indonesia. Sedangkan kontribusi penelitian ini dalam konteks ilmu pengetahuan dan sosial budaya, adalah untuk memberikan sumbangan pemikiran akademik menyangkut kajian hukum ekonomi syariah sebagai salah satu kajian tematik pemikiran hukum berbasis syariah. Pada tataran praktis, penelitian ini dapat memberikan manfaat sebagai rekomendasi kepada para pemangku kebijakan di Indonesia, untuk menyusun suatu produk undang-undang yang mengatur model dan transaksi perjanjian syariah yang dipraktikkan pada beberapa lembaga keuangan syariah, agar tetap konsisten dengan prinsip-prinsip syariah.

\section{Perjanjian dalam perspektif syariah Islam}

Istilah perjanjian dalam Islam menggunakan terminologi akad yang dalam al-Qur'an menggunakan istilah al-'aqd. Pengertian akad secara bahasa adalah ikatan, mengikat. Dikatakan ikatan (al-rabth) maksudnya adalah menghimpun atau mengumpulkan dua ujung tali dan mengikatkan salah satunya pada yang lainnya hingga keduanya bersambung menjadi seperti seutas tali yang satu. Kata al-'aqd terdapat dalam al-Qur'an Surah Al-Maidah Ayat 1 bahwa manusia diminta untuk memenuhi akadnya (Pasaribu dan Lubis, 2004: 1).

Menurut Faturrahman Djamil dalam Ghufron, istilah al-'aqd ini dapat disamakan dengan istilah verbintennis dalam BW (Mas'adi, 2002: 75). Sedangkan istilah al-ahd dapat disamakan dengan istilah perjanjian atau overeenkomst, yaitu suatu pernyataan dari seseorang untuk mengerjakan atau tidak mengerjakan sesuatu yang tidak berkaitan dengan orang lain. Istilah ini terdapat dalam Qur'an Surah Ali Imran Ayat 76, yaitu "barangsiapa siapa yang menepati janji yang dibuatnya dan bertakwa, maka sesungguhnya Allah menyukai orang-orang yang bertakwa. Para ahli hukum Islam memberikan definisi akad sebagai pertalian antara ijab dan Kabul yang dibenarkan oleh syara' yang menimbulkan akibat hukum terhadap objeknya (Bashir, 2000: 247). Abdurrahman mengemukakan terjadinya suatu perikatan dalam Islam melalui tiga tahap, sebagai berikut (Djamil, 2001: 247-248): 1) Al-'ahdu (perjanjian), yaitu pernyataan dari seseorang untuk melakukan sesuatu atau tidak melakukan sesuatu dan tidak 
ada sangkut pautnya dengan kemauan orang lain. Janji ini mengikat orang yang menyatakannya untuk melaksanakan janji tersebut; 2) Persetujuan, yaitu pernyataan setuju dari pihak kedua untuk melakukan sesuatu atau tidak melakukan sesuatu sebagai reaksi terhadap janji yang dinyatakan oleh pihak pertama. Persetujuan tersebut harus sesuai dengan janji pihak pertama; 3) Apabila dua buah janji dilaksanakan maksudnya oleh para pihak, maka terjadilah apa yang dinamakan 'aqd, maka yang mengikat masing-masing pihak sesudah pelaksanaan perjanjian itu bukan lagi perjanjian atau 'abd tetapi 'aqd.

Dalam perikatan Islam, terkandung tiga unsur untuk dapat terpenuhinya sebuah akad yaitu; 1) Adanya pertalian ijab dan kabul, yaitu pernyataan dari seseorang untuk melakukan sesuatu atau tidak melakukan sesuatu; 2) Persetujuan yaitu pernyataan setuju dari kedua belah pihak; 3) Adanya pelaksanaan perjanjian yang disebut 'aqd.

Sedangkan menurut, pendapat As-Sabatin (2011: 37), rukun akad ada tiga: (1). Dua pihak yang berakad (al-'aqidān); (2) Objek akad (maḥâl al-'aqad); (3) Redaksi akad (sighât al'aqad). Namun menurut Yusuf as-Sabatin, ada beberapa jenis akad tertentu yang meskipun telah sempurna ketiga rukunnya tersebut, misalnya sudah terlaksana ijab-qabul, tetapi belum terlaksana sebelum berlangsungnya serah terima zat harta yang menjadi objek akad tersebut. Contoh akad-akad tersebut, akad hibah, al-qard (hutang) dan al-rabn (agunan), dan lain-lain.

Prinsip mendasar dalam perjanjian berbasis syariah adalah muatan akad perjanjian yang dilakukan tidak boleh bertentangan dengan syariah atau hal-hal yang diatur oleh Allah swt. dalam al-Qur'an dan Nabi Muhammad saw. dalam hadis. Pelaksanaan akad, tujuan akad, maupun objek akad tidak boleh bertentangan dengan syariat. Jika bertentangan, akan mengakibatkan akad itu tidak sah. Sebagai contoh, suatu perikatan mengandung riba atau objek perikatan yang tidak halal (seperti minuman keras), mengakibatkan tidak sahnya suatu perikatan menurut hukum Islam.

\section{Konsep muḍārabah dalam perspektif perjanjian syariah}

Al-Fairuz Abadi di dalam al-Qāmūs al-Muḥit mengatakan: Mudāabah secara bahasa: almudărabah dari daraba; d̦arabat al-tayru tadribu berarti pergi mencari rezeki; daraba fi al-ardhi darban wa dharbānan: keluar berdagang atau berperang, atau bergegas atau pergi. D araba fi alardi bermakna safar (bepergian) seperti dinyatakan dalam Quran Surah al-Nisa' [4]: 
ljtihad, Jurnal Wacana Hukum Islam dan Kemanusiaan, Volume 15, No. 1, Juni 2015: 119-136

101. Adakalanya bepergian itu untuk mencari rezeki (QS al-Muzammil:73). Menurut Ibn Manzhur di dalam Lisan al-'Arab, kata mudärib digunakan untuk menyebut al-ämil, sebab dialah yang bepergian, datang dan pergi mencari rezeki. Mudāabah adalah istilah penduduk Irak dan lebih banyak digunakan oleh mazhab Hanafi dan Hanbali.

Penduduk Hijaz menyebut mudārabah dengan qirād atau muqāradah (Nasrodin, 2009:242), yang lebih banyak digunakan oleh ulama mazhab Syafii dan Maliki. Secara istilah, mudärabah atau qirä, adalah persekutuan badan dengan harta. Maknanya, seseorang menyerahkan hartanya kepada orang lain agar orang lain itu membisniskan harta tersebut dengan ketentuan keuntungan yang diperoleh dibagi kepada mereka sesuai dengan kesepakatan.

Badan tersebut adalah kiasan dari tenaga yang menjadi andil salah satu pihak dalam mudărabah tersebut. Mudarabah itu bisa dalam tiga bentuk. Pertama: mudārib ikut andil modal ditambah modal dari syarik (mitra) lainnya. Kedua: mudärib hanya andil tenaga, sementara modal dari syarik lainnya, misal antara satu orang pengelola dengan dua orang pemodal. Ketiga: dua orang sama-sama mengelola dengan modal berasal dari salah satu di antara mereka (Erna Susana dan Annisa Prasetyanti, 2011: 467). Bentuk ketiga ini oleh Ibn Qudamah dalam Al-Mughni wa Syarh al-Kabir dinilai sebagai bentuk mudārabah. Mudärabah adalah shirkah (kemitraan) yang halal secara syar'i. Al-Kasani dalam Badäi' al-sanäì' menyatakan bahwa orang-orang biasa melakukan akad mudārabah dan Nabi saw. tidak mengingkari mereka sehingga hal itu merupakan persetujuan (taqrïr) dari Nabi atas kebolehan mudärabah.

Al-Daraquthni meriwayatkan bahwa Hakim bin Hizam juga menyerahkan harta sebagai mudāarabah dan mensyaratkan seperti syarat al-'Abbas. Al-Baihaqi meriwayatkan dari al-'Ala' bin Abdurrahman bin Ya'qub dari bapaknya dari kakeknya bahwa Utsman memberikan harta secara mudarabah. Ibn Abi Syaibah meriwayatkan dari Abdullah bin Humaid dari bapaknya dari kakeknya bahwa Umar ra. pernah menyerahkan harta anak yatim secara mudarabah. Imam al-Syaukani dalam Nayl al-Awthar, setelah memaparkan sejumlah atsar itu, menyatakan bahwa atsar-atsar ini menunjukkan bahwa mudārabah dilakukan oleh para Sahabat tanpa ada seorang pun yang mengingkari sehingga hal itu menjadi ijmak mereka bahwa mudărabah adalah boleh. Ibn al-Mundzir di dalam al-Ijmä' menyatakan bahwa para ahli ilmu telah berijmak atas kebolehan mudärabah secara keseluruhan. Rukun akad mudärabah ada tiga. 
Pertama, dua pihak yang berakad. Kedua, Al-sighat, yaitu ijab dan qabul. Ketiga, obyek akad (al-ma'qūd 'alayh), yaitu amal (aktivitas), modal dan keuntungan. Akad mudarabah hanya sah dilakukan oleh mereka yang secara syar'i sah melakukan tasarruf, yaitu orang yang berakal, baligh dan tidak sedang di-bijr (dilarang oleh hakim untuk melakukan tacarruf, termasuk melakukan transaksi finansial). Dua pihak yang berakad (al-äqidān) yang dimaksud bukan jumlahnya harus dua orang, melainkan dua pihak itu adalah satu pihak yang menjadi müjib (menyampaikan ijab/ajakan) dan pihak yang menyampaikan qabul. Al-sighat atau ijab dan qabul harus dilakukan terpaut antara ijab dan qabulnya atau harus dalam satu majelis akad.

Di dalam ijab-qabul ini harus jelas andil dari masing-masing syarik (mitra), artinya harus jelas siapa yang menjadi mudärib (pengelola) dan siapa yang menjadi pemodal. Obyek akad (al-ma'qūd 'alayh) mud̄ärabah yaitu al-'amal, ra's al-māl (modal) dan al-ribḥu (laba). Terkait al'amal, sebagai shirkah maka dalam mudärabah harus jelas aktivitas bisnis yang diakadkan. Harus dipahami dengan jelas batasan aktivitas yang termasuk dalam cakupan bisnis dalam shirkah itu, atau yang menjadi cakupan aktivitas mudärib (Suryati, 2012: 1).

Kejelasan ini penting sehingga semua pihak dapat menakar andil al-'amalitu dalam bisnis dan hasilnya. Hal itu bisa menjadi pertimbangan penting untuk membuat kesepakatan tentang pembagian laba. Kejelasan itu juga penting untuk menentukan batasan pekerjaan yang masih dalam cakupan aktivitas pengelolaan shirkah dan mana yang tidak. Terkait ra's al-măl atau modal maka ada beberapa ketentuan: 1) Modal haruslah 'aynan (zat harta) dan ada pada waktu akad, tidak boleh berupa utang atau piutang yang ada di pihak lain; 2) Modal hendaknya dalam bentuk dinar (emas), dirham (perak) atau uang sehingga nilai nominalnya jelas. Ketentuan ini merupakan jumhur ulama; 3) Jika berupa barang, komidoti, jasa atau manfaat seperti manfaat ruko misalnya, maka para ulama berbeda pendapat tentang kebolehannya. Jika berupa barang, komoditi atau manfaat maka harus disepakati nilainya atau dinominalkan pada saat akad; 4) Jumlah modal harus jelas pada saat akad shirkah. Hal ini penting untuk mengetahui besarnya laba nantinya.

Mudâarabah tidak sah kecuali modal seluruhnya diserahkan atau menjadi berada dalam kekuasaan mudärib pada saat akad shirkah. Tidak boleh ada sebagian modal yang diutang atau diserahkan kemudian. Akad mudärabah mengharuskan hal itu. Aktivitas finansial (bisnis) 
ljtihad, Jurnal Wacana Hukum Islam dan Kemanusiaan, Volume 15, No. 1, Juni 2015: 119-136

yang diakadkan itu dilakukan terhadap modal dan hal itu langsung berlaku sejak akad dilangsungkan sehingga modal yang diakadkan seluruhnya harus diserahkan kepada mudärib. Adapun terkait al-riḅ̣ (laba) maka harus diperhatikan: 1) Besarnya nisbah keuntungan yang menjadi bagian masing-masing syarik, baik pengelola maupun pemodal, harus disepakati. Besarnya nisbah laba itu bisa disepakati dengan memperhatikan porsi andil masingmasing baik tenaga maupun modal; bisa juga tanpa memperhatikan hal itu. Besarnya laba tidak boleh ditentukan nilai nominalnya, tetapi hanya berupa nisbah atau prosentase atas laba. Jika ditentukan nilai nominalnya, menurut Ibn Qudamah dalam Syarḥal-Kabir, membuat akad mudarabah itu batil; 2) Kerugian finansial hanya menjadi tanggungan modal. Ali bin Abi Thalib berkata: "Kerugian itu berdasarkan harta (modal), sedangkan keuntungan berdasarkan kesepakatan mereka (para mitra)" (HR Abdurraqaq dan Ibn Abi Syaibah). Merujuk dari situ maka shirkah itu mencakup wakalah dan wakil tidak menjamin dan kerugian hanya ditanggung pihak yang mewakilkan, kecuali kerugian itu karena kesengajaan wakil. Selain itu, bagian laba dan tanggungan kerugian itu mengikuti andil. Badan tidak menanggung kerugian harta, melainkan merugi tenaga, waktu dan pikiran yang dicurahkan saja; 3) Pembagian laba dilakukan setelah dihitung rugi-labanya dan modal disisihkan (dikembalikan ke pemodal). Untuk itu harus ditentukan periode shirkah, bisa pertransaksi, harian, mingguan, bulanan, tahunan; sesuai dengan fakta bisnis dan mempertimbangkan kemaslahatan pengelola sebab ia bisa jadi bergantung pada pembagian laba itu sebagai penghasilannya.

Apabila akad mudārabah sempurna, maka konsekuensinya hak mengelola shirkab itu hanya dimiliki oleh mudärib. Ia berhak menjalankan shirkah itu sesuai pandangan dan pendapatnya sendiri. Pemodal tidak memiliki hak atas pengelolaan shirkah itu. Sebab, akad mudārabah itu terjadi atas badan pengelola dan harta pemodal, bukan atas badan pemodal jadi pemodal menjadi seperti orang asing dari shirkah itu sehingga ia tidak berhak atas pengelolaan shirkah tersebut. Namun pemodal boleh menetapkan syarat-syarat atas pengelolaan shirkah itu pada saat akad. Mudärib wajib terikat dengan syarat-syarat yang ditetapkan itu dan tidak boleh menyalahinya sebab ia mengelola shirkah itu sesuai dengan izin sehingga ia terikat dengan izin yang diberikan.

Mudarib tidak boleh bekerja kepada shirkah yang ia kelola. Sebab, akad mudärabah itu terjadi atas badannya dan aktivitas pengelolaan shirkah itu menjadi konsekuensi dari akad 
tersebut. Namun, jika pekerjaan itu di luar cakupan aktivitas, pengelolaan shirkah dan tidak mengganggu pengelolaan shirkah maka orang yang menjadi mudaribitu boleh mengerjakannya dan mendapat upah. Misal, mengecat toko, sementara bisnis shirkah-nya adalah perdagangan. Adapun pemodal, ia boleh bekerja kepada shirkah yang ia modali itu. Sebab, badan pemodal itu tidak menjadi obyek akad shirkah dan ia seperti orang asing dari shirkah itu.

Shirkah termasuk 'aqd jaiz sehingga masing-masing boleh membatalkan akad shirkah mudarabah kapan saja. Jika salah seorang syarik meninggal maka akad shirkabitu batal. Namun, harus diingat, akad shirkah termasuk 'aqd mustamirr, secara otomatis diperbaharui seiring waktu. Jika satu periode shirkah berakhir, atau ada yang menarik diri, maka secara otomatis akad shirkah itu diperbarui untuk semua syarik yang tidak menarik diri.

Untuk memperkuat analisis penelitian ini, penulis menggunakan instrumen penelitian yang mengacu kepada tipe penelitian hukum (legal research) normatif berbasis empiris. Tipe peneliian hukum normatif yang dimaksud disini adalah suatu tipe penelitian hukum yang bermaksud untuk menemukan aturan hukum, prinsip-prinsip hukum, dan doktrin-doktrin hukum guna menjawab isu hukum yang dihadapi (Marzuki, 2005: 22).

Mengingat tipe penelitian ini menggunakan tipe penelitian hukum normatif, maka pendekatan masalah yang digunakan adalah pendekatan konseptual. Melalui pendekatan ini, penulis hendak menggali serta memformulasikan konsep syariah dalam perjanjian mudārabah yang berlangsung dalam praktik perjanjian di perbankan syariah Indonesia. Selain itu, tipe penelitian hukum normatif ini juga berbasis kepada pendekatan empiris. Maksudnya, peneliti melakukan observasi atau pengamatan empirik terhadap beberapa transaksi perjanjian syariah yang menggunakan nomenklatur mudärabah sebagaimana dipraktikkan oleh beberapa bank syariah di Indonesia.

Secara metodologis, keberlangsungan penelitian ini akan berlangsung pada beberapa tahapan yang mencakup tahap pengumpulan bahan hukum yang bermula dari pengumpulan bahan-bahan hukum primer lalu diolah serta diverifikasi oleh penulis. Hasil olahan tersebut, menjadi dasar analisis penulis untuk menghasilkan format baru doktrin hukum yang dapat dipertanggungjawabkan secara akademik. Selanjutnya, hasil olahan primer akan dikuatkan dengan observasi di lapangan dengan mengunjungi beberapa bank syariah di Kota Kendari seperti Bank Muamalat Kendari, BNI Syariah Kendari, dan Bank Mandiri Syariah Kendari, 
ljtihad, Jurnal Wacana Hukum Islam dan Kemanusiaan, Volume 15, No. 1, Juni 2015: 119-136

sehingga dapat dihasilkan kesimpulan ilmiah guna menjadi sumbangan penting operasionalisasi kegiatan lembaga perbankan syariah tersebut dalam kerangka tetap menjaga prinsip-prinsip murni syariah keseluruhan.

\section{Telaah kritis nomenklatur akad mudarabah pada perbankan syariah}

Berdasarkan hasil observasi peneliti terhadap realitas transaksi yang berlangsung antara Bank Syariah dengan para nasabah, maka tampak bank syariah telah menempatkan kedudukannya, sebagai subjek hukum dengan status Perseroan Terbatas (PT). Pada sisi lain, ketika dalam konteks Bank Syariah yang menempatkan nasabah dalam kedudukan sebagai penyimpan dana. Maka Bank Syariah akan mendudukkan dirinya sebagai pihak yang menerima dana dari masyarakat atau sebagai penyimpan dana masyarakat. Sebagai lembaga penyimpan dana masyarakat, maka tentu saja Bank Syariah haruslah menjaga kepercayaan masyarakat terhadap dana yang disimpan itu.

Pada sisi ketika Bank Syariah berkedudukan sebagai penyalur dana kepada nasabah yang membutuhkan dana misalnya untuk kepentingan modal usaha atau untuk kepentingan lainnya, maka pihak bank akan menempatkan dirinya sebagai pihak yang memberikan bantuan dana. Umumnya konteks kedudukan bank tersebut, adalah sebagai șạhibul māl. Di sinilah kemudian bank difiksikan sebagai pemilik modal. Sebab pada faktanya dengan mencermati keberadaan bank syariah sebagai penyimpan dana masyarakat, maka hakikatnya nasabah penyimpan dana itulah yang secara riil merupakan pemilik modal, sedangkan pihak bank syariah sematamata sebagai pemberi jasa yang menyimpan dana-dana nasabah.

Pada konteks pembahasan ini, penulis hendak menelaah secara kritis kedudukan hukum (legal standing) Bank Syariah yang berlangsung dalam praktik-praktik transaksi keuangan yang berlabel syariah tersebut. Terutama dalam konteks transaksi keuangan syariah yang menggunakan skema mudärabah. Ini penting dilakukan mengingat transaksi keuangan kita, tidak bisa dipungkiri, masih terkooptasi dengan sistem transaksi keuangan berbasis kapitalisme. Begitu kuatnya pengaruh sistem keuangan kapitalisme yang melingkari hubungan transaksional masyarakat muslim saat ini, sangat dikhawatirkan bila transaksi keuangan berlabel syariah justeru terjebak dalam sistem kapitalisme. Sehingga alih-alih hendak menjaga kemurnian transaksi syariah namun justeru terjebak dalam lingkaran kekufuran kapitalisme yang sangat 
bertentangan dengan ajaran Islam itu sendiri.

Kritik pertama terhadap kedudukan hukum Bank Syariah, yaitu sampai saat ini bentuk badan hukum Bank Syariah secara umum masih menggunakan status hukum Perseroan Terbatas (PT). Padahal karakteristik PT merupakan aplikasi dari bentuk badan usaha perseroan modal yang dikenal dalam skema transaksi berbasis ekonomi kapitalisme.

Dalam peristilahan bahasa Arab, PT dikenal dengan nama shirkah qubra al-musāhamah. Tentu saja, jika dicermati secara mendalam maka bentuk badan usaha yang dipersonifikasikan oleh bank-bank syariah di Indonesia dengan menyandang status PT dari segi syariah masih merupakan sesuatu yang bermasalah dari segi syariah.

Alasannya karena realitas Perseroan Terbatas, dalam praktiknya merupakan bentuk badan usaha yang melanggar syariah. Hal ini ini, menurut penulis dapat dilihat dari beberapa aspek menyangkut kedudukan PT secara normatif, yang tidak menempatkan para pesero (pemegang saham) secara individual sebagai pihak yang bertanggungjawab secara hukum terhadap kewajiban yang ditanggung ketika melakukan transaksi dengan pihak ketiga. Artinya dalam PT, para pesero tidak terlibat dalam akad transaksi untuk melakukan suatu kegiatan usaha tertentu. Kapasitas para pesero (pemegang saham), yang bergabung kedalam perseroan bukan berdasarkan kepada akad yang diperjanjikan tetapi didasarkan kepada penyertaan modal. Karena dalam PT yang terjadi adalah aktivitas pemodalan (saham) yang diperjanjikan maka dalam PT itu sendiri, tidaklah berlangsung transaksi berpijak atas akad ijab kabul antara para pihak yang melakukan pekerjaan. Yang tampak adalah aktivitas individual yang sifatnya sepihak dengan memperhatikan jumlah modal yang masuk. Semakin besar modal (saham) yang dimiliki oleh seseorang maka semakin besar kewenangan yang ia miliki dalam mengelola perusahaan. Besarnya kewenangan yang dimiliki oleh pemilik modal terbesar, akan terlihat pada Rapat Umum Pemegang Saham (RUPS).

Sehingga apa yang menjadi kebijakan perusahaan berbentuk PT, termasuk dalam hal penunjukan seorang direksi atau manajer, sangat tergantung dari pemegang saham mayoritas (pihak yang memiliki modal besar) dalam perusahaan. Sejatinya, dalam PT yang berlangsung adalah kehendak individual bukan karena kehendak kolektif.

Adapun direksi dan komisaris yang mengelola dan menjalankan aktivitas usaha perseroan bukanlah para pendiri persero, meskipun yang duduk sebagai anggota dewan direksi dan 
komisaris adalah para pendiri sendiri. Sebab yang mengangkat dewan direksi dan komisaris adalah RUPS berdasarkan jumlah suara terbanyak (jumlah saham terbanyak) yang notabene adalah modal. Jadi yang mengelola perseroan terbatas tersebut adalah "orang abstrak" (maksudnya modal) bukan pendiri perseroan.

Dalam perspektif syariah, perserikatan usaha dalam PT adalah melanggar akad syariah, mengingat dalam PT, pembentukan perseroan terbatas dilakukan oleh dua orang atau lebih dengan memberikan investasi berupa modal agar bisa mendapatkan pembagian keuntungan (deviden) atau kerugian dari usaha yang dijalankannya. Modal perseroan tersebut dalam bentuk saham (Di Indonesia pendirian perseroan terbatas dilakukan dengan akta notaris dan menjadi badan hukum jika sudah disahkan oleh menteri kehakiman). Tentu saja, hal itu sangat berbeda dengan perseroan dalam Islam. Perseroan dalam Islam adalah transaksi antara dua orang atau lebih yang bersepakat melakukan kerja yang bersifat finansial dengan tujuan mencari keuntungan, sehingga harus ada ijab dan kabul dari para perseronya. Maksudnya harus ada seseorang mengajak pihak lainnya untuk melakukan suatu kerja sama usaha.

Transaksi dalam Perseroan Terbatas (PT), yang terjadi adalah transaksi antar modal dan tidak ada sama sekali unsur manusia meskipun yang menggerakkan modal tersebut adalah manusia, sehingga modal-modal itulah yang melakukan perseroan bukan orang-orangnya. Dengan demikian transaksi tersebut tidak melibatkan dua pihak atau lebih dan tidak terdapat ijab dan kabul, maka menurut hukum syariah hal itu belum dapat disebut sebagai transaksi. Akibat hukum tidak sahnya transaksi tersebut adalah perseroan terbatas yang didirikan dianggap tidak sah sebagai suatu perseroan atau shirkah dalam pandangan syariah.

Pelanggaran kedua PT menurut perspektif syariah, adalah Perseroan Terbatas (PT) hanyalah transaksi modal dan modal itulah yang mengelola perseroan dan bukannya individuindividu persero (orang yang bertransaksi membentuk perseroan), sehingga yang mengembangkan kepemilikan harta/kekayaan dalam perseroan terbatas adalah berdasarkan modal itu sendiri. Sementara dalam Islam pengembangan kepemilikan harus lahir dari aktivitas manusia, yaitu para persero yang bersepakat membentuk perseroan. Bukan didasarkan sematamata karena kepemilikan modal.

Pelanggaran syariah lainnya dari Perseroan Terbatas juga terletak pada tanggung jawab terbatas. Jika perusahaan rugi atau bangkrut para kreditur dan pemilik hak lainnya tidak 
dapat menuntut para persero perusahaan sedikitpun, berapapun kewajiban perusahaan terhadap mereka. Mereka hanya bisa menuntut atas haknya sebatas aset perusahaan yang tersisa.

Kritik selanjutnya penulis terhadap transaksi mudärabah yang berlangsung di beberapa Bank Syariah, adalah status ganda yang dimiliki Bank Syariah, yang pada satu sisi menempatkan dirinya sebagai pelaku usaha (muḍarib) dan pada sisi lain sebagai pemilik modal (șạhib al-māol). Padahal secara riil sejatinya Bank Syariah tidak memiliki modal, sebab modal yang diklaim sebagai milik modal itu sesungguhnya milik nasabah yang disimpan.

Berikut penjelasan skenario status ganda Bank Syariah. Bank Syariah menghimpun dana dari nasabah pertama yang datang menabung dengan akad mudärabah, dalam hal ini bank memposisikan nasabah sebagai pemilik modal dan bank syariah sendiri mengklaim sebagai pelaku usahanya (mudärib), ketika uang modal sudah dalam penguasaan bank, maka bank tidak menjalankan dengan amanah apa yang semestinya dilakukan oleh pihak pelaku usaha dalam akad mudărabah namun justru bank kembali mengikat diri lagi dengan perjanjian mudārabah kepada pihak lain yakni nasabah kedua. Dalam konteks kedua ini bank mengklaim sebagai pemilik modal (sāhạib al-māal) dan nasabah yang datang kali ini adalah pihak pelaku usaha (mudạrib) sesungguhnya yang benar-benar membutuhkan curahan bantuan modal untuk usahanya.

Menyimak skenario tersebut, maka dapat diketahui terdapat dua akad mudărabah yang dilakukan bank syariah tersebut, yaitu akad muḍarabah dengan nasabah pertama ketika bank memposisikan diri sebagi pelaku usaha dan akad mudärabah dengan nasabah kedua ketika bank kemudian memposisikan diri sebagi pemilik modal.

Akan tetapi, seandainya bank melakukan muḍarabah dengan nasabah kedua atas ijin pemilik modal (nasabah pertama) maka bank tidak berhak mendapat bagian keuntungan dan menentukan nisbah bagi hasil karena statusnya hanya sebagai perantara atau makelar dana saja. Para ulama menjelaskan bahwa hasil keuntungan dalam akad mudârabah hanya milik pemodal dan pelaku usaha, sedangkan pihak yang tidak memiliki modal dan tidak ikut serta dalam pelaksanaan usaha maka tidaklah berhak untuk mendapatkan bagian dari hasil keuntungan (bagi hasil). Para ulama melarang peraktek mudāabah yang dilakukan bank syariah saat ini sebagaimana yang dikemukakan oleh Imam Nawawi yang di kutip dan dibenarkan dalam sejumlah kitab-kitab fikih klasik para ulama salaf: Imam an-Nawawi menyatakan 
bahwa hukum kedua: tidak dibenarkan bagi pelaku usaha (mudāarib) untuk menyalurkan modal yang ia terima kepada pihak ketiga dengan perjanjian mudāabah. Bila ia melakukan hal itu atas seizin pemodal, sehingga ia keluar dari akad muḍarabah (pertama) dan berubah status menjadi perwakilan bagi pemodal pada akad muḍarabah kedua ini, maka itu dibenarkan. Akan tetapi ia tidak dibenarkan untuk mensyaratkan untuk dirinya sedikitpun dari keuntungan yang diperoleh. Bila ia tetap mensyaratkan hal itu, maka akad mudarabah kedua bathil. Ucapan senada juga diutarakan oleh Imam Ibnu Qudamah bahwa tidak dibenarkan bagi pelaku usaha untuk menyalurkan modal (yang ia terima) kepada orang lain dalam bentuk muḍarabah, demikian penegasan Imam Ahmad. Pendapat ini adalah pendapat Imam Abu Hanifah, al-Syafi'i dan aku tidak mengetahui ada ulama' lain yang menyelisihinya.

Bila kita mencermati konstruksi perjanjian mudärabah yang berlangsung pada beberapa bank syariah maka kita akan dapati sejumlah klausula dalam perjanjian dimaksud yang sesungguhnya tidak berada dalam kerangka mudärabah menurut bingkai syariah. Apa yang dilabelkan oleh Bank Syariah sebagai sebagai akad mudāabah jika dicermati sesungguhnya memuat sejumlah klausula yang berada pada tataran akad utang piutang.

Sehingga kamuflase akad mudärabah yang berlangsung pada perbankan syariah tidaklah merubah hakekat sebenarnya pada susbtansi akad utang piutang dalam skenario status ganda bank. Berikut ini kita cermati skenario akad utang piutang yang dijalankan oleh bank syariah meskipun mengelabui umat dan melabeli namanya dengan akad mudāabah: Pihak bank yang dalam status pertama sebagai pelaku usaha dan menerima modal dari nasabah pertama (di asumsikan sebagai kreditur), kemudian tidak amanah untuk menjalankan perannya sebagai pelaku usaha sesuai akad muḍarabah dimaksud, akan tetapi bank syariah malah kemudian menyalurkan kembali dana tersebut kepada pihak nasabah lain (diasumsikan sebagai debitur) yang hendak bertindak sebagai pelaku usaha.

Pada skema perjanjian tersebut, bank memposisikan diri sebagai pemodal yang pada hakekatnya uang modal yang ada pada bank merupakan uang milik nasabah pada akad muḍarabah pertama. Jadi subtansi dari skenario status ganda perbankan ini ialah bank berupaya mengalokasikan dana terhimpun dari pihak lain yang dijanjikan akan kembali dananya oleh bank seiring waktu berjalan beserta bagi hasilnya (bunga uang). Hal ini berjalan dari suatu usaha kosong yang pada hakekatnya tidak pernah bank lakukan kecuali hanya menerima 
dan menyalurkan dana serta mengambil keuntungan atasnya (menyerupai pinjaman bank terhadap uang nasabah pada bank konvensional yang disertai bunga pinjaman).

Aliran uang nasabah pertama tadi kemudian, dialokasikan oleh bank syariah dalam bentuk penyaluran dana kepada pihak lainnya (bank syariah pada hakekatnya bukan pemilik uang yang sebenarnya), dimana bank kali ini menuntut pengembalian dana seiring waktu berjalan beserta bagi hasilnya (bunga uang) atas modal yang hakekatnya bukan milik bank namun milik nasabah pertama yang berperan sebagai kreditur. Pada kedua proses tadi diisyaratkan adanya keuntungan atasnya, sebagaimana telah kita ketahui bahwa pengambilan keuntungan dari utang piutang adalah riba.

\section{Rekonstruksi model perjanjian muḍārabah pada perbankan syariah}

Menurut pendapat penulis, untuk merekonstruksi nomenklatur perjanjian mudārabah pada perbankan syariah yang masih mengandung cacat dari sudut pandang syariah, memang sangat sulit untuk dilakukan. Terutama bila paradigma sistem ekonomi yang menjadi penyangga tegaknya lembaga perbankan syariah masih bertumpu fondasi ideologi ekonomi kapitalisme. Sebab menurut penulis inspirasi kelahiran perbankan syariah sebetulnya bermula dari gagasan lembaga perbankan konvensional yang dibidani oleh kelompok pemilik modal yang lahir dari sistem ekonomi kapitalistik. Keberadaan perbankan sejatinya memang merupakan sebuah lembaga keuangan yang sebelumnya tidak pernah dikenal dalam sistem ekonomi Islam, baik semasa pemerintahan Rasulullah maupun masa pemerintahan khulufaur rasyidin sampai dilanjutkan pada masa-masa keemasan kekhilafahan Islam. Dalam sistem pemerintahan Islam, satu-satunya lembaga keuangan yang dikenal memiliki otoritas sebagai penyelenggara lalu lintas keuangan dan moneter, yaitu baitul mal.

Karakteristik lembaga perbankan yang bila ditilik dari sudut pandang historis yang sejatinya berbasis ribawi, maka memang tidak dapat dipungkiri bila hakikat keberadaan lembaga perbankan syariah juga mesti direkonstruksi agar keberadaannya sebagai lembaga yang menjalankan transaksi keuangan, yang tidak berjalan di atas fondasi berkarakteristik persis seperti apa yang dijalankan oleh lembaga perbankan konvensional pada umumnya.

Hal yang perlu direkonstruksi menurut penulis, terlebih dahulu mengubah secara radikal legal standing lembaga perbankan syariah. Dalam hal ini, lembaga perbankan syariah tidak 
ljtihad, Jurnal Wacana Hukum Islam dan Kemanusiaan, Volume 15, No. 1, Juni 2015: 119-136

didirikan dengan konsep perseroan ala PT yang kapitalistik. Keberadaan lembaga perbankan syariah, dalam perspektif ini, tidak lagi semata dipandang kumpulan modal (saham), tetapi perseroan mudärabah (qirad) adalah perseroan yang dibentuk oleh pihak penyandang dana

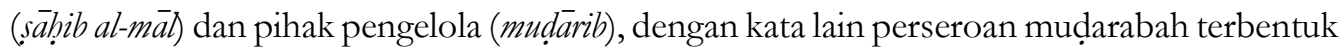
dengan meleburnya harta dan badan. Laba yang diperoleh dari usaha perseroan mudārabah dibagi berdasarkan kesepakatan sedangkan kerugian usaha (kewajiban perseroan) ditanggung oleh șăhib al-māl.

Dalam konteks demikian, legal standing Bank Syariah memang seharusnya tidak berjalan atas skema ganda sebagaimana yang berlangsung saat ini, yaitu pada satu sisi sebagai pengumpul dana masyarakat dan pada sisi lain mendudukkan diri sebagai șạhib al-māl hanya karena bersandarkan kepada modal yang disimpan itu yang seolah-olah milik bank yang pada hakikatnya milik nasabah penyimpan. Dengan demikian perlu skema baru yaitu dimana pihak bank seharusnya berstatus sebagai mediator yang menengahi antara mudärib dengan șăhib al-māl. Bank Syariah bisa meminta kuasa kepada beberapa nasabah penyimpan dana untuk digunakan modal simpanannya pada kegiatan-kegiatan usaha tertentu yang halal yang memang dibutuhkan oleh mudärib. Tentu saja, konsep keuntungan yang diskemakan adalah konsep bagi hasil (profit sharing). Bank Syariah sebagai kuasa dari nasabah șăhib al-mālmemang tidak berhak atas keuntungan yang diperoleh dari transaksi mudāabah tersebut.

Yang menjadi catatan penting dari klausula perjanjian yang dibangun antara șăhaibul māal dan mudărib yaitu nilai bagi hasil yang dipatok șạ̣ib al-māl tidaklah berdasarkan nilai nomianl tertentu tetapi harusnya berdasarkan kepada prosentase keuntungan yang diperoleh. Bila konsep bagi hasil didasarkan kepada nilai nominal tertentu maka akad mudarabah itu tidak sah.

Klausula dalam akad mudārabah juga tidak boleh memperjanjikan bahwa bila terjadi kerugian yang dialami pada saat keberlangsungan mudarabab itu sendiri maka mudarib wajib mengembalikan modal yang digunakan kepada șạhib al-māl. Sebagaimana klausula ini kerap terjadi pada beberapa perbankan syariah di negara ini. Sebab dalam mudārabab kerugian finansial hanya ditanggung oleh săhịib al-māl kecuali kerugian waktu dan tenaga ditanggung oleh mudārib.

Namun yang menjadi persoalan saat ini, gagasan skema akad mudārabah tersebut, sangat sulit dipraktekkan dalam sistem kehidupan masyarakat yang sudah terjebak dalam bingkai 
sistem ekonomi kapitalistik. Nasabah bank syariah sebagai penyimpan dana tidak akan pernah rela modal yang disimpannya raib begitu saja. Inilah yang menjadi problematika saat ini dimana filosofi akad mudarabah tidak dipahami betul sebahagian masyarakat kita saat ini.

\section{Penutup}

Berdasarkan pembahasan penulis dengan mengacu pokok rumusan masalah maka dapat ditarik pokok kesimpulan sebagai berikut: Anatomi perjanjian mudărabah yang dipraktikkan pada perbankan syariah di Indonesia memang secara prinsip perlu dikritisi sebab ada beberapa klausula dalam perjanjian yang diduga kuat melanggar prinsip-prinsip syariah, seperti legal standing Bank Syariah dalam perjanjian yang berstatus ganda. Yang perlu dikritisi lagi adalah kedudukan badan usaha perbankan syariah yang pada umumnya masih status badan hukum PT yang merupakan duplikasi bentuk badan usaha yang dikenal dalam sistem kapitalisme. Adapun menyangkut klausula perjanjian mudärabab di perbankan syariah jika dicermati secara jeli sesungguhnya masih terjebak pada skema utang piutang antara Bank Syariah selaku șăhib al-măl dengan nasabah selaku mudärib tentu skema demikian sangat riskan menjebak para pihak kedalam riba.

Berdasarkan kesimpulan tersebut penulis merekomendasikan rekonstruksi ulang skema akad mudārabah yang berlangsung dalam beberapa bank syariah di Indonesia, maka yang sangat mendesak adalah para pemangku kebijakan di negara ini yang berkepentingan dengan penerapan prinsip-prinsip murni syariah dalam transaksi keuangan, hendak menyusun suatu paket kebijakan konkrit untuk merancang cetak biru nomenklatur lembaga keuangan syariah yang betul-betul murni syariah dengan melibatkan para fuqaha, ahli hukum Islam, dan ulamaulama yang siqah terpercaya dari sisi keilmuan dan ketakwaannya.

\section{Daftar pustaka}

Al-Sabatin, Yusuf. Bisnis Islam dan Kritik atas Praktik Bisnis ala Kapitalis. Bogor: Al-Azhar Press, 2011.

Bashir, Ahmad Azhar. Asas-Asas Hukum Muamalat. Yogyakarta: UII Press, 2000.

Djamil, Faturrahman. Hukum Perjanjian Syariah dalam Kompilasi Hukum Perikatan. Cet. 1, Bandung: Citra Aditya Bakti, 2001.

Marzuki, Peter Mahmud. Penelitian Hukum. Jakarta: Kencana Prenada Media Group, 2005. 
ljtihad, Jurnal Wacana Hukum Islam dan Kemanusiaan, Volume 15, No. 1, Juni 2015: 119-136

Mas'adi, Ghufron A. Fiqib Muamalah Kontekstual. Cet. 1. Jakarta: Raja Grafindo Persada, 2002.

Nasrodin. "Analisis Fiqihterhadap Implementasi Pembiayaan Modal Kerja IB pada PT Bank Tabungan Negara (Persero), TBK Kantor Cabang Syariah Jogjakarta,” dalam Jurnal Ekonomi Islam Lariba, Vol. III No. 2 Des. 2009.

Pasaribu, Chairuman dan Lubis, Suhrawadi K. Hukum Perjanjian dalam Islam, Jakarta: Sinar Grafika, 2004.

Suryati. "Pengaruh Pembiayaan Muḍarabah terhadap Perkembangan Usaha dan Pendapatan

Nasabah Muḍarabah di BMT Binamas Purworejo," dalam Jurnal Pendidikan dan Ekonomi, Vol. 1 No. 2 Tahun 2012.

Susana, Erni dan Prasetyanti, Annisa. "Pelaksanaan dan Sistem Bagi Hasil Pembiayaan AlMuḍarabah Pada Bank Syariah,” dalam Jurnal Kenangan dan Perbankan, Vol.15 No. 3 Sept. 2011. 